ATTHULAB:

Islamic Religion Teaching $\mathcal{E}$ Learning Journal

Volume 4 Nomor 2 Tahun 2019

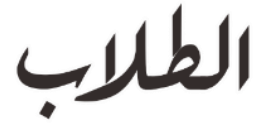

http://journal.uinsgd.ac.id./index.php/atthulab/

\title{
Etika guru PAI menurut Imam Nawawi (analisis ilmu pendidikan Islam)
}

\author{
Dadan Nurlhaq1), Miftahul Fikri2) dan Shopiah Syafaatunnisa ${ }^{3)}$ \\ Jurusan Pendidikan Agama Islam \\ Universitas Islam Negeri Sunan Gunung Djati Bandung \\ Jalan Soekarno Hatta Kota Bandung Jawa Barat 40629 Indonesia \\ 1) Email: dadannh@uinsgd.ac.id \\ 2) Email: miftahulfikrisiwa@uinsgd.ac.id \\ 3)Email: shopiahsyafaatunnisa@gmail.com
}

\begin{abstract}
The Islamic scholarship from classical thinkers till now still contribute as reference for actualization by PAI Teachers. One of these thinkers was Imam Nawawi ad-Dimasyqi. The problem is: what is the urgency of teacher ethics from Imam Nawawi s idea for PAI Teachers? This research aims to analyze the urgency of teacher ethics from Imam Nawawi`s ideas for PAI Teachers. The method used is descriptive and content analysis. The technique uses library research and documentation. The results of this study reveal a conclusion that the urgency of teacher ethics from Imam Nawawi s ideas for PAI teachers: (a) relate with the profession: an attitude of caring for students; and (b) relate with the challenges of modern education: sincere intentions in teaching. If PAI teachers practice it, so they will improve quality, gain knowledge, and do their roles in totality.
\end{abstract}

$$
\begin{gathered}
\text { Keywords: } \\
\text { ethics; PAI teachers; Imam Nawawi }
\end{gathered}
$$

\begin{abstract}
Abstrak: Khazanah Islam yang kaya dari pemikir klasik hingga saat ini dapat menjadi referensi yang sesuai untuk diaktualisasikan oleh Guru PAI. Salah satu pemikir tersebut ialah Imam Nawawi ad-Dimasyqi. Persoalannya ialah: bagaimana urgensi etika guru menurut Imam Nawawi bagi Guru PAI? Penelitian ini bertujuan untuk mengetahui urgensi etika guru menurut Imam Nawawi bagi Guru PAI. Metode penelitian yang digunakan adalah deskriptif dan analisis konten. Adapun teknik pengumpulannya menggunakan studi kepustakaan dan dokumentasi. Hasil penelitian ini mengungkapkan suatu kesimpulan bahwa urgensi etika guru menurut Imam Nawawi bagi guru PAI: (a) berkenaan dengan profesi: sikap peduli terhadap murid; dan (b) berkenaan dengan tantangan pendidikan modern: niat yang ikhlas dalam mengajar. Dengan niat yang ikhlas dan sikap peduli terhadap murid, guru PAI akan meningkatkan kualitas, memperoleh keberkahan ilmu, dan dapat menjalankan perannya secara totalitas.

Kata Kunci:

etika; guru PAI; Imam Nawawi
\end{abstract}

DOI: http://dx.doi.org/10.15575/ath.v4i2.4682

Received: 05, 2019. Accepted: 10, 2019. Published: 11, 2019

\section{PENDAHULUAN}

Kualitas pendidikan suatu bangsa sangat ditentukan oleh kualitas para gurunya. Sebagus-bagusnya rancangan kurikulum, teknologi pendidikan, ataupun perencanaan pendidikan, jika tanpa guru yang berkualitas, maka tidak akan membawa kesuksesan dalam meraih tujuan pendidikan. (Alim, 2014). Artinya, keberhasilan proses pendidikan sangat ditentukan oleh kualitas para gurunya. Namun amat disayangkan, kualitas guru di negeri kita tercinta ini masih jauh dari harapan. Menurut Wakil Sekretaris Jenderal Komisi Nasional Pendidikan Sukmawardana, kualitas dan kompetensi guru masih 
sangat memprihatinkan saat ini. Hal tersebut dibuktikan dengan masih banyaknya guru yang malas mengembangkan kemampuan diri, tidak berpijak pada program mengajar, tidak menguasai metode mengajar yang dapat membuat minat belajar siswa meningkat. (Alim, 2014). Hal ini ditegaskan oleh Kementerian Pendidikan dan Kebudayaan (Kemendikbud), bahwa kompetensi guru masih sangat rendah. Dibuktikan dengan hasil Uji Kompetensi Guru (UKG) yang dilansir dari sindonews diakses pada hari Jumat, 3 Agustus 2012 di www.nasional.sindonews.com tentang Hasil UKG memprihatinkan, dari 243.619 guru, rata-rata hanya mendapatkan nilai 44,5 atau di bawah rata-rata nasional. (Zubaidah, 2012).

Fakta lainnya terungkap dalam penelitian yang dilakukan oleh seorang dosen Universitas Negeri Yogyakarta (UNY) mengenai minat baca guru Sekolah Dasar (SD) di Kabupaten Sleman 2011. Hasil penelitiannya menunjukan bahwa minat membaca sebagian besar guru masih dalam kategori rendah. (Sutrisno, 2012). Ironisnya lagi, bangsa ini juga sering dikejutkan oleh beberapa oknum guru yang asusila. Di antaranya berita mengenai mantan Kepala Sekolah di Batam divonis tujuh tahun penjara karena cabuli siswanya. Majelis Hakim Pengadilan Negeri Batam menjatuhkan vonis tujuh tahun penjara, denda Rp. 100 miliar subsider satu bulan kurungan pada mantan Kepala Sekolah SMP 28 Batam karena terbukti melakukan asusila pada siswanya saat masih menjabat. (Winarno, 2013). Bahkan asusila juga dilakukan oleh seorang guru agama atau guru ngaji. Contohnya mengenai kasus guru ngaji di Bangka Belitung ditangkap polisi disebabkan cabuli belasan murid. (Wahyono, 2018). Guru agama, yang seharusnya menjadi uswah, bahkan jalan dakwahnya disejajarkan dengan jalan dakwah para Nabi dan Rasul, tidak sepatutnya melakukan pelanggaran syari at.

Dari uraian di atas, jelaslah bahwa kualitas guru masih belum menggembirakan. Fakta-fakta tentang hasil UKG yang belum memenuhi standar, rendahnya minat baca guru, juga kasus-kasus asusila, menunjukan bahwa guru tersebut mengesampingkan etika. Tidak cukup bermodalkan cerdas pengetahuan saja, guru juga dituntut untuk cerdas dalam bersikap, menjujung tinggi etika pendidik. Utamanya guru PAI tentu harus mengikuti etika, baik yang diatur dalam undang-undang maupun pendidikan Islam. Etika-etika tersebut bahkan sifatnya wajib melekat dan tertanam. Sebagaimana diungkapkan Akhmad Alim, guru harus syarat dengan etika. Tanpa etika, dirinya tidak membawa manfaat.

Imam Nawawi yang hidup pada masa dinasti Mamluk di Damaskus memberikan sumbangsih pemikirannya mengenai etika guru yang dituangkan dalam sebuah kitab yang berjudul Adab al-Alim wa al-Muta'allim wa al-Mufti wa al-Mustafti yang pada asalnya merupakan muqaddimah dalam kitab Al-Majmu Syarh al-Muhadzdzab yang dijadikan kitab terpisah oleh penerbit dari Mesir agar memudahkan orang-orang yang mempelajarinya.

Ada banyak peneliti muslim yang berkiprah mendalami pemikiran Imam Nawawi rohimahullah. Para peneliti tersebut banyak melakukan analisis pada karya-karyanya. Alhasil, banyak sekali pemikiran beliau yang masih bisa diterapkan kemanfaatan ilmunya di era pendidikan saat ini. Dalam penelitian tersebut ada yang bertajukan nilai-nilai pendidikan, etika guru-murid, namun belum ada yang secara spesifik membahas pemikirannya yang secara khusus bersentuhan dengan kebutuhan isu guru PAI di zaman ini.

Jauh sebelum isu pentingnya etika diagung-agungkan, Imam Nawawi telah menuliskan nasihat-nasihatnya yang sarat dengan nilai-nilai pendidikan yang dibutuhkan saat ini. Etika guru yang beliau tulis tersebut sesuai untuk sosok guru PAI yang memiliki peranan penting sebagai publik figur. 


\section{METODE PENELITIAN}

Pada penelitian ini, peneliti menggunakan pendekatan kualitatif, yaitu suatu penelitian yang menekankan makna terpenting dari etika guru PAI menurut Imam Nawawi, menggunakan metode deskriptif dan analisis isi. Adapun teknik pengumpulan data menggunakan studi kepustakaan dan dokumentasi. Teknis analisis data ini meliputi tahapan-tahapan: mengolah dan mempersiapkan data untuk dianalisis; membaca keseluruhan data; meng-coding data; mengkategorikan data; menarasikan dalam bentuk laporan kualitatif; dan menginterpretasi data. (Creswell, 2010).

\section{HASIL PENELITIAN DAN PEMBAHASAN}

\section{A. Urgensi Etika Guru menurut Imam Nawawi bagi Guru PAI}

Pemikiran pendidikan Islam adalah hasil interaksi internal dan eksternal peradaban Islam yang berkesinambungan dan saling mengisi untuk memberi kontribusi bagi kemajuan umat Islam. Kontekstualisasi terhadap ide-ide para tokoh muslim tetap sebagai hal yang penting dilakukan dan tidak menganggapnya sebagai sesuatu hal yang telah kadaluarsa, karena meskipun kasusnya berbeda namun bisa saja memiliki pola permasalahan yang sama seperti krisis akhlak, pergeseran budaya, dan lain sebagainya. (Assegaf, 2013). Artinya, pentingnya mempelajari pemikiran tokoh muslim saat ini tanpa mengesampingkan tokoh pendidikan muslim terdahulu. Sebab masing-masing tokoh tidak bisa berdiri sendiri, pemikiran mereka saling mengisi dan saling membutuhkan. Islam memiliki khazanah intelektual yang kaya untuk kemajuan pendidikan Islam. Pemikiran dari tokoh klasik sekalipun masih berlaku selama ide tersebut sesuai dengan kebutuhan pendidikan di zaman sekarang, atau justru permasalahan saat ini yang mengalami kemiripan dengan pola permasalahan yang dialami oleh pemikir itu di zamannya.

Imam Nawawi, meskipun gagasannya muncul sebagai pegangan bagi guru di masanya, seorang pendidik Islam yakni guru PAI, tetap dapat menerapkan pemikirannya yang sesuai dengan kebutuhan pendidikan saat ini. Ia harus mampu memahami persoalan pendidikan yang semakin kompleks dan banyak bermunculan. Ia dituntut untuk memahami khazanah pendidikan Islam yang luas dalam rangka memelihara keberkahannya sebagai seorang guru yang mengajarkan mata pelajaran yang mulia dan suci. Atas dasar itulah, ia pun dituntut untuk bisa menerapkan gagasan Imam Nawawi yang sangat penting sehingga bisa berperan memberikan solusi atas permasalahan pendidikan yang dihadapi saat ini, juga dapat meningkatkan profesionalitasnya sebagai guru PAI.

\section{Berkenaan dengan Profesi}

Pada saat ini diperlukan guru yang mempunyai kepribadian yang menyenangkan murid, yang dapat dijadikan kakak yang dapat memahami perkembangan jiwanya, yang dapat meredakan gejolak emosinya, yang dapat meredakan hatinya serta membimbingnya ke arah pertumbuhan sosial yang sehat dan wajar. (Ramayulis, 1994). Pribadi guru yang memahami murid ini sangat diperlukan demi tercapainya pendidikan yang bermutu. Sebab di era kompetitif ini hanya pendidikan bermutu yang dapat membawa manusia untuk survive di masa yang akan datang. (Putra Daulay, 2012). Oleh karena itu, salah satu faktor pendukung pendidikan yang bermutu ialah guru yang dekat dengan murid juga mampu memahami muridnya. Seorang guru PAI harus turut andil dalam menciptakan pendidikan yang bermutu tersebut.

Kemampuan guru di dalam memahami murid dapat diwujudkan dalam bentuk kasih sayang. Para tokoh pendidikan Islam yang lain sangat banyak memperhatikan 
pentingnya sikap kasih sayang seorang guru. Di antaranya Ibnu Miskawaih menekankan perlunya hubungan yang didasarkan pada cinta kasih antara guru dan murid yang akan berdampak pada keberhasilan pendidikan. (Nata, 2000). Tak hanya itu, Al-Mawardi menyatakan bahwa seorang guru harus tampil sebagai penyayang karena guru berperan sebagai orang tua di sekolah sehingga menuntutnya untuk memiliki sifat kasih sayang dan lemah lembut. Kasih sayang dan lemah lembut ini sejalan dengan psikologi manusia, bahwa kegairahan dan semangat belajar seorang murid tergantung pada hubungan antara murid dan guru. Apabila guru bersikap kasar dan tidak bersikap kasih sayang, dapat menyebabkan murid kurang senang dan tidak mau menerima pelajaran yang diberikan. Secara psikologis, setiap manusia lebih suka diperlakukan dengan cara-cara yang lembut. (Nata, 2000). Maka jelaslah apa yang dikatakan al-Ghazali, bahwa sifat terpenting yang harus dimiliki oleh seorang guru adalah rasa kasih sayang. Sebab, hal inilah yang akan menyebabkan murid merasa tentram pada gurunya sehingga mereka termotivasi untuk menguasai ilmu yang diajarkan oleh gurunya. Agar murid termotivasi untuk belajar PAI, maka guru PAI harus memiliki sikap kasih sayang.

Seorang guru adalah orang yang akan mengantarkan murid menjalani hidupnya di masa yang akan datang. Maka guru harus menatap ke depan, ia mampu mendampingi mereka untuk menyongsong masa depannya. Ia juga harus dapat menyampaikan pengalaman hidupnya agar dapat diambil pelajaran oleh mereka. Namun, guru juga harus menyadari bahwa apa yang ia alami dahulu pasti berbeda dengan apa yang dihadapi oleh anak didik yang sedang dibimbingnya. Oleh karena itu, hendaknya ia selalu membuka diri dengan mengaitkan pengalaman-pengalaman yang diperolehnya dahulu dengan keadaan yang sedang dihadapinya. (Assegaf, 2013). Hal ini sebagaimana dikatakan oleh Ali bin Abi Thalib:

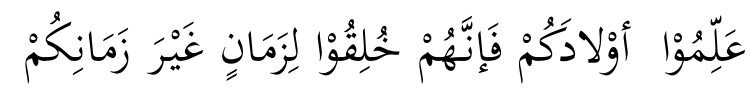

"Didiklah anak-anak kalian dengan hal-hal yang tidak seperti apa yang kalian pelajari. Sesungguhnya mereka itu diciptakan dalam zaman yang berbeda dengan zaman kalian diciptakan." (Shihab, 2015).

Sebagai seorang guru PAI, ia harus peduli pada nasib muridnya di masa yang akan datang. Sehingga cara mengajarnya pun disesuaikan dengan tuntutan zaman. Sistem pembelajaran di abad 21 menuntut siswa untuk menguasai 4C (Communication, Collabotation, Critical Thinking and Problem Solving, dan Creative and Innovative). Selanjutnya, ada integrasi literasi, penguatan pendidikan karakter, dan HOTS (Higher Order Thinking Skills). (Apandi, 2018). Sebagai konsekuensinya, seorang guru harus semakin berkualitas dalam melaksanakan kegiatan pembelajaran. Tantangan seorang guru semakin berat, karena ia tidak hanya sebatas menjembatani, tapi juga harus mengerti bagaimana siswa belajar untuk menghadapi zamannya. Artinya, seorang guru PAI harus kompeten di era global saat ini.

Guru PAI harus mampu mengimbangi zaman global yang semakin kompleks menimpa peserta didik. Guru PAI harus pandai mengemas cara pengajarannya sehingga menghasilkan peserta didik yang berkualitas baik dari segi imtaq maupun iptek. Dari segi imtaq, bagaimana agar siswa dapat meningkatkan ketakwaan serta melekatnya sikap religius dalam kepribadiannya. Sedangkan dari segi iptek, bagaimana agar siswa mampu mengikuti perkembangan zaman seperti menguasai IT, multibahasa (mastering english and arabic), dan lain-lain. Maka guru PAI tidak hanya mutlak menguasai PAI, zaman modern juga menuntutnya agar mampu mengimbangi kemampuan dirinya di era global dan dapat memahami apa yang menjadi kebutuhan 
muridnya di masa mendatang. Semua itu merupakan bagian dari tanggung jawab seorang guru PAI. Sebagaimana diungkapkan Abdurrahman Assegaf, guru yang bertanggung jawab senantiasa mengorbankan apapun yang ada pada dirinya demi keberhasilan anak didiknya. Tidak ada kebahagiaan lain yang dirasakan oleh seorang guru selain keberhasilan anak didik yang dibimbingnya. (Assegaf, 2013).

Rasa cinta dan kepedulian seorang guru inilah yang tak luput dari perhatian Imam Nawawi. Semua penjelasan di atas baik sikap kasih sayang, hingga cara mendidik guru untuk kepentingan masa depan muridnya, semua terangkum dalam poin etikanya:

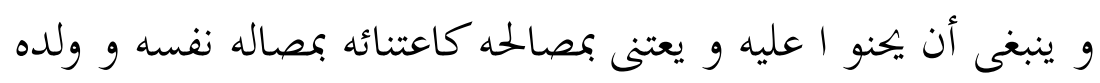

(An-Nawawi, 1987).

"Hendaknya seorang peduli pada murid seperti ia peduli pada dirinya dan anak kandungnya sendiri." Beliau menjelaskannya sebagai berikut:

Hal itu bisa ia lakukan dengan membantu dan mempersiapkan hal-hal yang para murid butuhkan. Guru harus menyayangi mereka sebagaimana sayangnya terhadap anak-anak kandungnya sendiri. Guru juga harus tetap perhatian dan sabar dalam menghadapi sifat-sifat bandel dan keras kepala dengan tetap mengingatkannya ke arah yang lebih baik. Sebab manusia memang tidak ada yang sempurna, artinya selalu ada kekurangan dalam dirinya. (Prihantoro, 2018).

Penjelasan Imam Nawawi di atas menggambarkan kepedulian seorang guru dengan senantiasa memberikan apa yang murid butuhkan, menyayanginya, memperhatikannya secara intens, sabar dalam menghadapi sifat buruknya dan dalam menasihatinya ke arah yang lebih baik, serta benar-benar memahami hakikat setiap peserta didik yang memiliki sisi kurang dan lebihnya masing-masing. Konsep guru yang peduli pada muridnya ini menjadi bagian terpenting untuk diamalkan oleh seorang guru PAI yang dapat diinterpretasikan menjadi sikap-sikap seperti: pribadi yang disenangi murid, pribadi yang dekat dengan murid, dan pribadi yang peduli pada masa depan murid. Hal ini sejalan dengan kode etik guru Indonesia pada kongres XXI PGRI Nomor VI Tahun 2013 Pasal 2 Ayat 1 bahwa kewajiban guru: bertindak profesional dalam melaksanakan tugas mendidik, mengajar, membimbing, mengarahkan, melatih, menilai dan mengevaluasi peserta didik untuk mewujudkan tujuan pendidikan nasional. Bahwa tujuan pendidikan nasional tidak akan tercapai apabila guru tidak memiliki kepedulian kepada muridnya dan rasa kasih sayang seperti kepada anak kandungnya sendiri.

Seorang guru PAI harus memiliki personifikasi keislaman yang baik yang diwujudkan dalam bentuk pribadi yang etis. Sikap etis yang berkenaan dengan profesinya ialah rasa kepeduliannya yang besar pada peserta didik. Sikap peduli ini harus terus ditanamkan dalam diri seorang guru PAI sehingga kesan PAI yang jenuh, kurangnya chemistry antara guru PAI dan murid, cara mengajar guru PAI yang monoton, dapat teratasi dengan sikap peduli. Dengan kepeduliannya, seorang guru PAI akan senantiasa menjadi pribadi yang disenangi murid, dekat dengan murid, peduli pada masa depan murid, sehingga berpengaruh juga pada kepribadiannya yang penuh kasih sayang serta keahliannya dalam menguasai metode kependidikan yang sesuai dengan tuntutan zaman.

\section{Berkenaan dengan Tantangan Pendidikan Modern}

Islam menjadi tumpuan harapan di tengah tantangan modern. Meskipun Islam sebagai agama yang memiliki kesiapan dalam menghadapi tantangan modern, tetapi tetap bergantung pada bagaimana sikap para pemeluknya di dalam memahami 
ajarannya itu sendiri. Umat Islam yang pemahamannya benar tentu meyakini fleksibilitas ajaran Islam di segala zaman, termasuk di zaman modern. Hal ini sebagaimana diungkapkan Ernest Geller tentang universalisme ajaran Islam, bahwa prinsip-prinsip ajaran Islam dapat diterapkan dimana saja dan kapan saja, hingga mampu menyerap tradisi dan budaya lokal. (Hasan, 2005).

Tantangan pendidikan modern yang saat ini sedang berlangsung adalah tantangan etis religius. Istilah ini sebagaimana dijelaskan Muhammad Tholhah Hasan, yaitu korban kehidupan dalam modernisasi materialis. Ia menggambarkanya dengan kehidupan emosional manusia yang mengalami erosi, dan berlanjut pada pemiskinan spiritual. Di negara-negara maju, terjadi kesenjangan antara manusia dengan Tuhannya; dan di negara-negara berkembang, terjadi kesenjangan antara orientasi keagamaan dengan tuntutan duniawinya. (Hasan, 2005). Kekeliruan kita selama ini dalam proses pendidikan adalah cenderung melakukan pendekatan material oriented, tentu saja hal ini berdampak terhadap pemiskinan peradaban. (Afifuddin, 2008).

Miskinnya spiritual dan peradaban menunjukan perlunya umat Islam menengok kembali konsep ulama terdahulu yang sangat krusial, terutama yang berkaitan dengan pendidikan rohani. Banyaknya permasalahan kemanusiaan di zaman ini karena tidak adanya kedekatan antara manusia dengan Allah SWT. Di sinilah perlunya umat Islam meningkatkan ketakwaan untuk memperbaiki hubungan tersebut. Pemikiran Imam Nawawi yang penuh sentuhan spiritual hadir sebagai solusi bagi tantangan pendidikan modern.

Sebagaimana telah dipaparkan sebelumnya bahwa diantara tantangan pendidikan modern bagi seorang guru PAI ialah krisis spiritual. Sedangkan Al-Ghazali menyatakan bahwa ilmu yang baik adalah ilmu yang menambah kualitas spiritual seseorang kepada Tuhan. Bahkan Ibnu Taimiyah berpandangan bahwa hasil akhir dari intelektualitas seseorang tampak pada kematangan spiritualnya. (Aziz, 2015). Hal ini mengisyaratkan bahwa sisi spiritual guru PAI amat sangat diperhitungkan.

Dalam Islam, terdapat sabda Nabi Saw. bahwa amal seseorang tergantung pada niat. Niat menjadi penentu amal seseorang sehingga posisinya sangat utama. Perkara niat adalah hal sangat urgen yang ditentukan seseorang sebelum melakukan perbuatan. Ia menjadi penentu baik tidaknya keislaman seseorang. Ia menjadi bagian penting dari spiritualitas seseorang. Bahkan menurut Ibnu Jama`ah, niat yang baik dan ikhlas bagi seorang guru akan membawa berkah, memperoleh hikmah dan pengetahuan yang berlimpah, hati yang terang, cita-cita yang tercapai, dan derajat yang tinggi pada hari kiamat (Ekonomi \& Mea, 2016).

Begitu besarnya implikasi niat dalam mempengaruhi sikap hidup seseorang. Atas dasar itulah, pemikir Islam menekankan urgensi sikap etis berupa niat yang benar. Imam Nawawi dalam pemaparan etikanya menyumbangkan gagasan terpenting mengenai niat:

$$
\text { أن يقصد بتعليمه وجه الله تعالى }
$$

(An-Nawawi, 1987, hal. 29).

Bahwa seorang guru hendaknya meniatkan segala aktifitas keilmuan baik belajar maupun mengajar semata-semata hanya untuk mencari ridha Allah SWT. Artinya, keikhlasan adalah hal yang sangat mendasar, gagasan ini mampu menjawab permasalahan pendidikan modern. Sebab dengan ikhlas, permasalahan seperti guru yang mengorientasikan pekerjaannya pada dunia tidak akan ditemukan lagi sehingga berimplikasi pada pembelajaran yang sesuai harapan. Tidak akan ada lagi guru yang 
melanggar aturan agama maupun kode etik guru, yang ada hanyalah guru yang taat yang dengan keikhlasannya ia mampu mengajar dengan sungguh-sungguh. Berikut ini penjelasan Imam Nawawi.

Seorang guru tidak boleh berniat untuk mencari kesenangan-kesenangan duniawi. Misalnya, memperkaya diri, ingin dikenal, atau memproklamasikan diri bahwa aktivitas keilmuan yang ditekuninya jauh lebih baik daripada yang lainnya. Seorang guru seharusnya tidak menodai proses belajar mengajarnya dengan keinginankeinginan untuk bisa memiliki banyak relasi dengan maksud mendapat pelayanan atau kompensasi, meskipun hanya sedikit saja. Bahkan, keinginan untuk mendapatkan hadiah sekalipun, dapat menodai kesucian niatnya. Seorang guru tidak menjadikan keuntungan-keuntungan duniawi sebagai tujuan mengajarnya. Ia harus mampu menghadirkan dalam dirinya bahwa mengajar adalah ibadah. Semua ini untuk menjaga niatnya dari hal-hal yang tidak terpuji. Sekaligus sebagai suatu peringatan agar guru jangan sampai kehilangan keberkahan dalam aktifitas mengajarnya. (Prihantoro, 2018).

Gagasan Imam Nawawi di atas menunjukan bahwa keridhoan Allah Swt. harus menjadi satu-satunya tujuan seorang guru demi menjaga kesucian niatnya. Semua aktifitas keilmuannya harus diniatkan sebagai ladang ibadah sehingga aktifitas keilmuannya diberkahi Allah Swt. Dengan tujuan ini, seorang guru akan terhindar dari hal-hal yang tidak terpuji. Di masa modern saat ini, banyak sekali guru yang mengabaikan pentingnya keberkahan. Sehingga sangat wajar apabila kekhawatiran Imam Nawawi rentan terjadi, banyak guru yang niatnya ternodai, seperti banyak kasus tidak terpuji berupa orientasi guru karena motif ekonomi, guru yang menginginkan kenaikan pangkat, dan lain-lain.

Hal ini sejalan dengan kode etik guru Indonesia pada kongres XXI PGRI Nomor VI Tahun 2013 Pasal 2 Ayat 1 bahwa kewajiban guru: bertindak profesional dalam melaksanakan tugas mendidik, mengajar, membimbing, mengarahkan, melatih, menilai dan mengevaluasi peserta didik untuk mewujudkan tujuan pendidikan nasional. Dalam menjalankan tugas keprofesionalannya, guru harus menjadi pribadi yang ikhlas agar kinerja akademiknya berkah dan berkualitas. Diantara tujuan pendidikan nasional yaitu berkembangnya peserta didik yang beriman dan bertakwa kepada Tuhan yang Maha Esa, yang salah satunya dapat diinterpretasikan dalam bentuk pribadi yang ikhlas hanya untuk mencari ridha Allah Swt. semata. Pribadi ikhlas dalam diri peseserta didik hanya mungkin terbentuk apabila seorang guru tersebut adalah pribadi yang ikhlas jua. Sebagai seorang guru PAI, keikhlasan menjadi syarat mutlak agar materi ikhlas yang ia ajarkan dapat sampai diresapi dan diamalkan peserta didik.

Apabila guru PAI bertugas dengan tidak dilandasi oleh keikhlasan, maka ia hakikatnya belum menaati syariat. Padahal, syarat seorang guru PAI adalah seorang muslim yang taat sebagaimana diungkapkan Afifuddin: "Guru dituntut harus memiliki kompetensi, baik profesional, personal, maupun sosial. Lebih-lebih bagi guru agama, ia harus menjadi pemeluk yang taat." (Afifuddin, 2008). Juga diungkapkan oleh Neong Muhadjir bahwa pendidik adalah seorang guru yang mempribadi (personifikasi pendidik), yaitu mempribadinya keseluruhan yang diajarkan, bukan hanya isinya, melainkan juga nilainya. (Suharto, 2011).

Wujud ketaatan seorang guru adalah ikhlas. Menurut Abuddin Nata, keikhlasan muncul dari keimanan yang teguh dan tulus kepada Allah SWT. Dalam hatinya ada perasaan yang kuat bahwa Allah SWT. maha melihat terhadap perbuatannya. Keikhlasan ini akan menjadi etos kerja yang amat kuat. Ia akan melakukan suatu pekerjaan dengan sungguh-sungguh disertai perasaan senang hati dan ringan. Tidak ada beban atau perasaan lain yang memaksanya (Nata, 2001). Makna keikhlasan seorang 
guru juga dipaparkan Al-Mawardi sebagai kesadaran akan pentingnya tugas, sehingga mendorongnya untuk mencapai hasil yang maksimal. Keikhlasan ini menjadi penentu keberhasilan tugasnya. Ia menjalankan tugas tersebut tanpa beban, melainkan penuh dengan rasa bahagia, penuh dengan harapan, karena keyakinan bahwa tugasnya akan mendapat pahala yang setimpal dari Allah Swt. Bagi Al-Mawardi, jika orientasi seorang guru adalah materi, maka ia akan mengalami kegoncangan ketika ia merasa bahwa kerja yang dipikulnya tidak seimbang dengan hasil yang diterimanya. Selain itu, guru tersebut akan sangat rentan terhadap persoalan yang ditemukan dalam tugasnya seperti soal kenaikan pangkat, hubungan dengan kepala sekolah, dan lain-lain. Hal ini akan mempengaruhi sikapnya terhadap peserta didik sehingga dapat merusak nilai pendidikan yang diterima peserta didik. (Nata, 2000). Dengan kata lain, orientasi yang salah dari seorang guru akan dapat menghambat keberhasilan transfer of value antara guru dan peserta didik.

Seorang guru yang ikhlas akan sampai kepada hati para muridnya, sehingga ikhlas sebagai kunci berhasilnya transfer of value yang saat ini banyak dipermasalahkan. Kinerja seseorang yang ikhlas itu tidak diragukan, karena ia akan bekerja secara totalitas semata-mata dalam rangka pengabdian-Nya kepada Allah. Seorang guru PAI yang ikhlas akan berusaha menjunjung tinggi profesionalitas dengan sebaik-baiknya. Selain itu, iapun akan melakukan semua tugasnya sebagai ladang ibadah. Sebagaimana diungkapkan Al-Mawardi, motif utama seorang guru adalah karena panggilan jiwanya untuk berbakti kepada Allah SWT dengan tulus ikhlas. (Nata, 2000). Prinsip totalitas ini sebagaimana diungkapkan oleh Haidar Putra Daulay: "Profesi kependidikan bukanlah perkerjaan sambilan yang ditangani setengah hati." (Daulay, 2006).

Al-Mawardi memiliki pandangan yang sama dengan Imam Nawawi, bahwa seorang guru dalam menjalankan tugas mendidik dan mengajar hendaklah diorentasikan untuk meraih ridha Allah Swt. Sebagai konsekuensinya, ia akan melaksanakan tugas guru dengan sebaik-baiknya serta penuh tanggung jawab. Beliau pun mengkritisi seorang guru yang menjalankan tugas karena motif ekonomi. Menurutnya, ilmu mempunyai nilai dan kedudukan yang tinggi yang tidak dapat disejajarkan dengan materi. (Nata, 2000).

Dengan demikian, seorang guru PAI harus memiliki personifikasi keislaman yang baik yang diwujudkan dalam bentuk pribadi guru yang etis. Sikap etis yang harus diaktualisasikan dalam merespon tantangan pendidikan modern adalah mengajar dengan ikhlas. Dengan konsep ini, diharapkan guru PAI akan mengabdikan diri dengan totalitas sehingga segala aktivitas kependidikannya diberkahi Allah Swt. Selain itu, dapat menjadi kunci berhasilnya transfer of value antara guru PAI dengan peserta didik.

Urgensi etika guru menurut Imam Nawawi bagi Guru PAI secara ringkas dapat diinterpretasikan dalam bentuk skema pada bagan 1. berikut. 


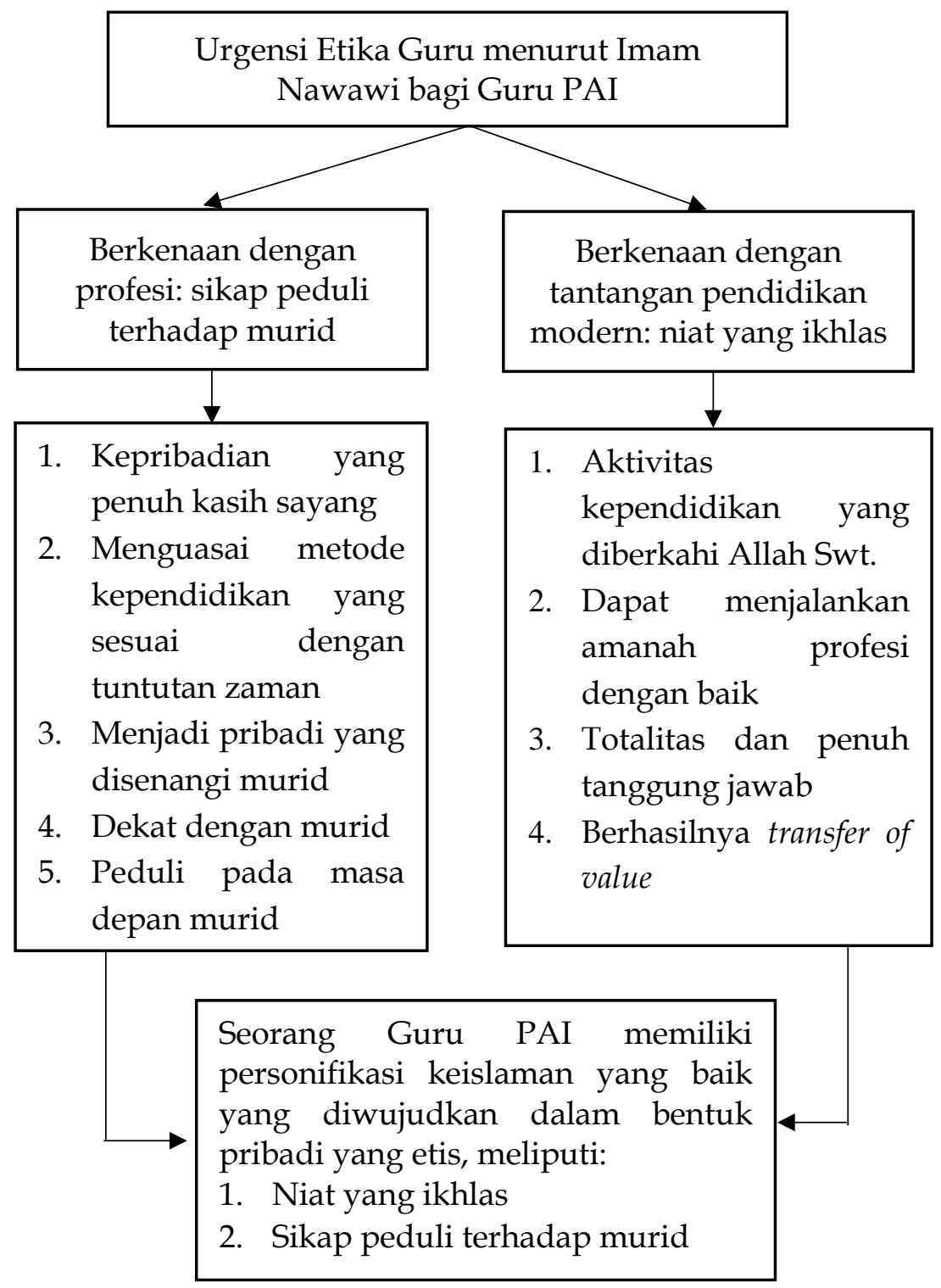

Bagan 1. Urgensi Etika Guru menurut Imam Nawawi bagi Guru PAI

\section{B. Pembahasan}

Islam sebagai agama yang fleksibel di segala masa, memiliki khazanah pemikiran yang juga berlaku di zaman modern saat ini. Pemikiran Imam Nawawi sebagai salah satu dari khazanah Islam yang kaya tersebut, memiliki andil yang sangat penting untuk zaman modern ini. Persoalannya ialah, apa sebetulnya urgensi etika guru menurut Imam Nawawi bagi guru PAI?

Berkenaan dengan profesi, pemikiran Imam Nawawi begitu urgen bagi guru PAI terlihat pada peran dari guru PAI itu sendiri. Secanggih apapun teknologi, tidak ada yang bisa menggantikan perannya. Pemikiran etika yang terpenting dari Imam Nawawi bagi guru PAI dalam hal ini adalah kepedulian terhadap peserta didik. Keharmonisan hubungan antara guru dan peserta didik adalah faktor pendukung pendidikan yang bemutu. Guru PAI tidak menganggap profesinya sebagai pekerjaan sambilan, tetapi sebagai amanah yang harus diperankan dengan sepenuh hati. Imam Nawawi mengajarkan agar guru peduli pada murid seperti pada anak kandungnya sendiri. Sebagai konsekuensinya, guru tersebut akan berusaha menjadi guru yang peduli pada 
masa depan muridnya yang menuntutnya untuk profesional sesuai dengan tuntutan zaman, ia akan meningkatkan kualitasnya, dan memastikan hubungannya dengan muridnya selalu harmonis. Profesi guru PAI yang berkualitas, sebagiannya disebabkan rasa peduli guru terhadap peserta didik. Dengan kepeduliannya itulah, guru akan senantiasa menjunjung tinggi nilai-nilai profesi.

Berkenaan dengan tantangan pendidikan modern, pemikiran Imam Nawawi pun begitu urgen bagi guru PAI. Hal terpenting dari pemikiran etikanya adalah niat yang ikhlas dalam mengajar. Sebab dengan ikhlas, permasalahan seperti guru yang mengorientasikan pekerjaannya pada dunia tidak akan ditemukan lagi sehingga berimplikasi pada pembelajaran yang sesuai harapan. Murid yang mampu menerapkan materi PAI dalam kehidupan, ilmunya diajarkan oleh seorang guru yang tulus dalam menyampaikannya. Dengan kekuatan ketulusan itulah, krisis moral di zaman modern ini sebagiannya dapat diminimalisir. Dalam konteks masa kini, tasawuf yang diajarkan Imam Nawawi ini merupakan rujukan yang diperlukan guru di tengah situasi moral yang sebagiannya sampai pada taraf yang mengkhawatirkan. Nuansa pendidikan yang sufistik sangat diperlukan guna membentuk sikap religius dan akhlak mulia.

\section{SIMPULAN}

Etika guru menurut Imam Nawawi menyumbangkan gagasan terpenting bagi guru PAI saat ini. Seorang guru PAI harus memiliki personifikasi keislaman yang baik yang diwujudkan dalam bentuk pribadi guru yang etis. Adapun pribadi etis berkenaan dengan profesi ialah sikap peduli terhadap peserta didik. Sedangkan yang berkenaan dengan tantangan pendidikan modern ialah niat yang ikhlas dalam mengajar. Dengan konsep yang digagasnya ini, diharapkan guru PAI akan meningkatkan kualitas, memperoleh keberkahan ilmu, dan dapat menjalankan perannya secara totalitas.

\section{REFERENSI}

Afifuddin, D. (2008). Spektrum Pendidikan Islam.

Alim, A. (2014). Tafsir Pendidikan Islam.

An-Nawawi. (1987). Adab al-`Alim wa al-Muta`allim wa al-Mufti wa al-Mustafti.

Apandi, I. (2018). Mewujudkan Pembelajaran Abad 21 dan HOTS melalui Penguatan Keterampilan Proses Guru dalam PBM.

Assegaf, A. R. (2013). Aliran Pemikiran Pendidikan Islam: Hadharah Keilmuan Tokoh Klasik sampai Modern.

Aziz, S. (2015). Pemikiran Pendidikan Islam Kajian Tokoh Klasik dan Kontemporer.

Creswell, J. (2010). Research Design Penelitian Kualitatif.

Daulay, H. P. (2006). Pendidikan Islam: Dalam Sistem Pendidikan Nasional.

Ekonomi, M., \& Mea, A. (2016). Edukasi Islami Jurnal Pendidikan Islam Vol . 05 , Januari 2016. 05, 1175-1183.

Hasan, M. T. (2005). Prospek Islam dalam Menghadapi Tantangan Zaman. 
Nata, A. (2000). Pemikiran Para Tokoh Pendidikan Islam; seri kajian filsafat pendidikan Islam.

Nata, A. (2001). Perspektif Islam tentang Pola Hubungan Guru-Murid Studi Pemikiran Tasawuf Al-Ghazali.

Prihantoro, H. A. (2018). Adabul `Alim Wal Muta`allim.

Putra Daulay, H. dan N. P. (2012). Pendidikan Islam dalam Mencerdaskan Bangsa.

Ramayulis. (1994). Metodologi Pengajaran Agama Islam.

Shihab, M. Q. (2015). Pengantin Al-Quran.

Suharto, T. (2011). Filsafat Pendidikan Islam.

Sutrisno, M. A. (2012). Pendidikan Islam Berbasis Problem Sosial.

Wahyono, D. (2018). Cabuli Belasan Murid, Guru Ngaji di Babel ditangkap Polisi.

Winarno, H. H. (2013). Cabuli Siswanya, Mantan Kepsek di Batam divonis 7 tahun penjara.

Zubaidah, N. (2012). Hasil Uji Kompetensi Guru Memprihatinkan. 